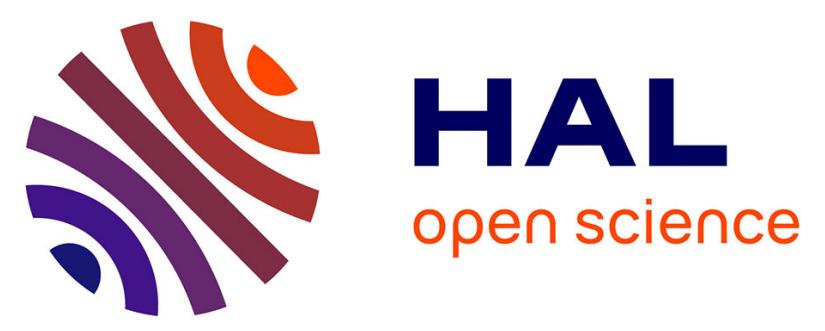

\title{
Thermal cycles, interface chemistry and optical performance of $\mathrm{Mg} / \mathrm{SiC}$ multilayers
}

\author{
H. Maury, Philippe Jonnard, K. Le Guen, J.-M. André, Z. Wang, J. Zhu, Jia
}

Dong, Zhen Zhang, Françoise Bridou, Franck Delmotte, et al.

\section{- To cite this version:}

H. Maury, Philippe Jonnard, K. Le Guen, J.-M. André, Z. Wang, et al.. Thermal cycles, interface chemistry and optical performance of $\mathrm{Mg} / \mathrm{SiC}$ multilayers. The European Physical Journal B: Condensed Matter and Complex Systems, 2008, 64 (2), pp.193-199. hal-00256010

\section{HAL Id: hal-00256010 https://hal.science/hal-00256010}

Submitted on 14 Feb 2008

HAL is a multi-disciplinary open access archive for the deposit and dissemination of scientific research documents, whether they are published or not. The documents may come from teaching and research institutions in France or abroad, or from public or private research centers.
L'archive ouverte pluridisciplinaire HAL, est destinée au dépôt et à la diffusion de documents scientifiques de niveau recherche, publiés ou non, émanant des établissements d'enseignement et de recherche français ou étrangers, des laboratoires publics ou privés. 


\section{Thermal cycles, interface chemistry and optical performance of}

\section{$\mathrm{Mg} / \mathrm{SiC}$ multilayers}

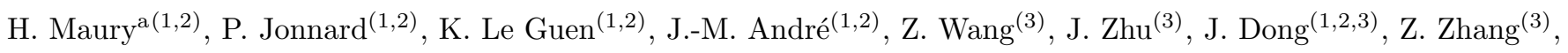

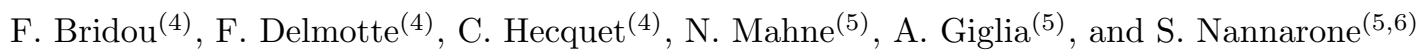

${ }^{1}$ UPMC Univ Paris 06, Laboratoire de Chimie Physique - Matière et Rayonnement, 11 rue Pierre et Marie Curie, F-75231 Paris Cedex 05, FRANCE

${ }^{2}$ CNRS, UMR 7614, 11 rue Pierre et Marie Curie, F-75231 Paris Cedex 05, FRANCE

${ }^{3}$ Institute of Precision Optical Engineering, Department of Physics, Tongji University, Shanghai 200092, CHINA

${ }^{4}$ Laboratoire Charles Fabry de l'Institut dOptique, CNRS, Univ Paris-Sud, Campus Polytechnique, RD 128, F-91127 Palaiseau cedex, FRANCE

${ }^{5}$ Laboratorio Nazionale TASC, INFM-CNR, s.s.14, km 163.5 in Area Science Park, I-34012 Trieste, ITALY

${ }^{6}$ Dipartimento di Ingegneria dei Materiali e dellAmbiente, Universita di Modena e Reggio Emilia, Via Vignolese 905, I-41100 Modena, ITALY

Received: February 4, 2008/ Revised version: date

Abstract. The interplay between optical performance and the thermally activated interface chemistry of periodic $\mathrm{Mg} / \mathrm{SiC}$ multilayers designed for application at $30.4 \mathrm{~nm}$ are investigated by optical (hard x-ray, soft $\mathrm{x}$-ray and ultraviolet ranges, i.e. from 0.154 to $30.4 \mathrm{~nm}$ ) reflectivity and x-ray emission spectroscopy. The multilayers are prepared by magnetron sputtering and then annealed up to a temperature of $500^{\circ} \mathrm{C}$. Two clear changes take place in the multilayer upon annealing. At first, between 200 and $300^{\circ} \mathrm{C}$ a strong decrease of the reflectivity is observed, due to the development of interfacial roughness following the crystallization of the $\mathrm{Mg}$ layers. No interfacial compound is detected. Then, between 350 and $400^{\circ} \mathrm{C}$ there is formation of the $\mathrm{Mg}_{2} \mathrm{Si}$ magnesium silicide at the interfaces following the reaction between the $\mathrm{Mg}$ and SiC layers. This also leads to the almost total loss of reflectivity of the multilayer. Thus, this kind of multilayer is thermally stable only for application requiring no heating above $200^{\circ} \mathrm{C}$.

PACS. 68.65.Ac Multilayers - 61.05.cm X-ray reflectometry (surfaces, interfaces, films) - 78.70.En X-ray emission spectra and fluorescence - 73.90.+f Other topics in electronic structure and electrical properties of surfaces, interfaces, thin films, and low-dimensional structures - 66.30.Ny Chemical interdiffusion; diffusion barriers - 68.35.Fx Diffusion; interface formation 


\section{Introduction}

Periodic multilayers consisting of an alternating and periodic succession of optically dense and less dense films are widely used nowadays as diffractive optical elements in the $\mathrm{X}-\mathrm{UV}$ range [1]. For the $30 \mathrm{~nm}$ region, the $\mathrm{Mo} / \mathrm{Si}$ system has been commonly employed because of its high time and thermal stability $[2,3]$. Its reflectivity ranges from 15 to $20 \%$ in the $25-35 \mathrm{~nm}$ spectral range. However for applications like solar imaging or photoemission microscopy using the He II line $(30.4 \mathrm{~nm}, 40.7 \mathrm{eV})$ multilayers with high reflecting power are needed. Thus $\mathrm{Si} / \mathrm{Mo}_{2} \mathrm{C}, \mathrm{Si} / \mathrm{B}_{4} \mathrm{C}$, $\mathrm{Si} / \mathrm{C}$ and $\mathrm{Si} / \mathrm{SiC}$ multilayers have been developed for this spectral range [4]. The $\mathrm{Si} / \mathrm{B}_{4} \mathrm{C}$ system features a good reflectivity but poor temperature and time stabilities, while $\mathrm{Si} / \mathrm{SiC}$ was found inadequate due to a measured reflectivity of only $16 \%$. It has been proposed to replace silicon by magnesium in multilayers because of the low absorption coefficient of the $\mathrm{Mg}$ atoms after the $\mathrm{L}$ absorption edge at $25 \mathrm{~nm}(50 \mathrm{eV})$. Ejima et al. have proposed $\mathrm{Mg} / \mathrm{SiC}$ multilayers and measured a reflectivity of $20 \%$ at $30.4 \mathrm{~nm}$ [5]. More recently, Takenaka et al. have obtained a reflectivity as high as $40 \%$ with the $\mathrm{Mg} / \mathrm{SiC}$ multilayer at the same wavelength [6].

Because of its recent development, the $\mathrm{Mg} / \mathrm{SiC}$ system has been little characterized. For example, with respect to Mo or $\mathrm{Si}, \mathrm{Mg}$ is highly reactive and has a relatively low melting point $\left(649^{\circ} \mathrm{C}\right)[7-10]$. These properties could lead to a difficulty in controling the time and thermal stability

a On leave to CEA.

Correspondence to: Dr. P. Jonnard; jonnard@ccr.jussieu.fr of the $\mathrm{Mg} / \mathrm{SiC}$ multilayers, despite their high reflectivity.

It is thus important to investigate the phenomena that take place at the interfaces and limit the performances of the system, in order to understand how interdiffusion and roughness develop as a function of the annealing. It may then be possible to obtain knowledge-based $\mathrm{Mg} / \mathrm{SiC}$ structures both optimized for thermal and time stabilities.

In this paper, we present the study of periodic $\mathrm{Mg} / \mathrm{SiC}$ multilayers prepared by magnetron sputtering and designed for application at $30.4 \mathrm{~nm}(40.7 \mathrm{eV})$. They are analysed by a combination of non-destructive techniques [11-14]: $\mathrm{x}-$ ray reflectivity (XRR) in the hard and soft $\mathrm{x}$-ray ranges, UV reflectivity (UVR) and x-ray emission spectroscopy (XES), in order to obtain structural and chemical informations about the $\mathrm{Mg} / \mathrm{SiC}$ stack together with the monitoring of the optical performances in the working range. The study is performed for the sample obtained by magnetron sputtering and for samples annealed at temperatures up to $500^{\circ} \mathrm{C}$

\section{Experimental details}

The $\mathrm{Mg} / \mathrm{SiC}$ multilayers, consisting of 30 bilayers, were deposited onto silicon substrates by an ultrahigh vacuum direct current magnetron sputtering system with four 100mm-diameter sputtering sources (JGP560C, made in China). The base pressure of this sputtering system reaches $\sim$ $1 \times 10^{-4} \mathrm{~Pa}$ before deposition. The working gas is argon $(99.999 \%$ purity) at the constant pressure of $0.1 \mathrm{~Pa}$ The sputtering sources work at the constant power mode, regulated at $10 \mathrm{~W}$ and $60 \mathrm{~W}$ for $\mathrm{Mg}$ and $\mathrm{SiC}$ targets, re- 
spectively. Substrates in size of $20 \mathrm{~mm} \times 30 \mathrm{~mm}$ were cut from a polished single-crystal Si (100) wafer. During the deposition of each layer, the substrate was kept stationary over the sputtering source for the time required to deposit the desired thickness. The multilayer was fabricated by alternate facing the substrate in front of each target. The deposited multilayer was then measured, for quality control and depositing rate control, by using a small angle x-ray diffractometer (D1 system, Bede Ltd., UK). The measurements show that the layer thicknesses of $\mathrm{Mg}$ and $\mathrm{SiC}$ are $12.1 \mathrm{~nm}$ and $4.7 \mathrm{~nm}$, respectively, see table 1 .

Some samples are annealed during $1.25 \mathrm{~h}$ (this does not include the times for increasing and decreasing the temperature) under argon atmosphere or in vacuum in the preparation chamber of the XES apparatus. The annealing temperatures range from 100 to $500^{\circ} \mathrm{C}$ with a $50^{\circ} \mathrm{C}$ step. For the samples dedicated to the XRR analysis at $0.154 \mathrm{~nm}$ the temperature step is $100^{\circ} \mathrm{C}$. The samples are analysed by specular optical reflectivity at three different wavelengths ranging from hard x-rays to ultra-violet. XRR at $0.154 \mathrm{~nm}(\mathrm{Cu} \mathrm{K} \alpha$ emission at $8048 \mathrm{eV})$ is performed with a home-made apparatus [15] for the annealed samples. All the multilayers are analysed by XRR at $1.33 \mathrm{~nm}$ ( $\mathrm{Cu} \mathrm{L} \alpha$ emission at $932 \mathrm{eV}$ ) with a home-made spectrogoniometer [16].

For the as-prepared samples, UVR measurements at $\sim 30.4 \mathrm{~nm}$ were taken in $\theta-2 \theta$ mode in the $5^{\circ}-35^{\circ}$ range in $s$-incidence at BEAR beamline [17] at Elettra. The photon energy was calibrated by a He gas absorption cell; the calibrated value resulted $40.70 \mathrm{eV}(30.4 \mathrm{~nm})$. The $\theta$ go- niometer angular resolution was $\frac{1}{100}^{\circ}$. Energy resolution $\frac{E}{\Delta}$, beam divergence and spot dimension of the incident beam at the sample were respectively: $\sim 1000,20 \mathrm{~m} \rho \times$ $20 \mathrm{~m} \rho$ (horizontal $\times$ vertical), $400 \mu \mathrm{m} \times 200 \mu \mathrm{m}$ (horizontal $\times$ vertical). Impinging and reflected intensities were measured by an IRD SXUV100 solid state diode within two separate runs; incident intensities were monitored by a $\mathrm{Au}$ mesh inserted in the beam path whose drain current was used for normalisation. The reflectometer features an overall accuracy on the absolute reflectivity of $\sim 1 \%$.

The x-ray spectra are measured with the IRIS (Instrument for Research on Interfaces and Surfaces) equipped with a high-resolution wavelength dispersive spectrometer [18]. The x-rays are produced by electron irradiation. In the case of the analysis of the $\mathrm{Si}$ emission band, the electron energy $(4 \mathrm{keV})$ is carefully chosen so that no signal can come from the silicon substrate. No evolution of the intensity and lineshape of the emission bands is detected with the number of accumulations, indicating that the electron irradiation conditions have no significant effect on the sample.

\section{Results and discussion}

\subsection{As-prepared samples}

The Mg $3 p$ and Si $3 p$ valence states are studied by XES through the $\mathrm{Mg} \mathrm{K} \beta$ and $\mathrm{Si} \mathrm{K} \beta$ emissions originating from the $3 p-1$ s transition. In fact, the $\mathrm{Mg}$ and $\mathrm{Si} 3 \mathrm{p}$ valence states are very sensitive to the chemical state $[19,20]$ of the $\mathrm{Mg}$ and $\mathrm{Si}$ atoms and give information about the com- 
pounds formed at the interfaces of the $\mathrm{Mg} / \mathrm{SiC}$ multilayers. We compare the spectra from the multilayers to those from reference compounds: a Mg polished plate, a $\mathrm{Mg}_{2} \mathrm{Si}$ powder (from Alfa Æsar, 99,5\% purity), a SiC crystalline powder (from Alfa Æsar, 99,8\% purity), a $250 \mathrm{~nm}$ thick $\mathrm{SiC}$ film deposited in the same conditions as the SiC layers of the $\mathrm{Mg} / \mathrm{SiC}$ stacks and a $\mathrm{MgO}$ single crystal. If no interaction takes place within the multilayer, one should observe the $\mathrm{Mg}$ lineshape of $\mathrm{Mg}$ in pure metal and that of $\mathrm{Si}$ in $\mathrm{SiC}$.

We present in figure 1 the spectra from the reference compounds that demonstrate the chemical dependence of the $\mathrm{x}$-ray valence band emissions. The $\mathrm{Mg} \mathrm{K} \beta$ spectra (figure 1a) of $\mathrm{Mg}$ and $\mathrm{Mg}_{2} \mathrm{Si}$ can be easily distinguished by their shape and the position of their maximum. In the same way, the $\mathrm{Si} \mathrm{K} \beta$ spectrum (figure $1 \mathrm{~b}$ ) of $\mathrm{Mg}_{2} \mathrm{Si}$ is clearly distinct from those of the $\mathrm{SiC}$ samples. The two $\mathrm{SiC}$ samples present differences: for the crystalline powder the main peak is narrower and the structure around $1827 \mathrm{eV}$ is better resolved. The high energy broadening could be ascribed to the presence of occupied defect states in the forbidden gap of the amorphous sample, the slight low energy narrowing to the difference between the crystalline and amorphous states and the poor resolution of the $1827 \mathrm{eV}$ structure for the amorphous samples to the fact that the stoichiometry of the film is not exactly that of $\mathrm{SiC}[21]$.

The spectra of the as-prepared multilayers are shown in figure 2 in comparison with $\mathrm{Mg}$ metal for the $\mathrm{Mg} \mathrm{K} \beta$ emission (Fig. 2a) and with crystalline $\mathrm{SiC}$ for the $\mathrm{Si} \mathrm{K} \beta$ emission (Fig. 2b). For the sake of clarity, only a limited number of references is displayed. It is clear, within the sensitivity of the method, that the magnesium atoms in the multilayer are in the metallic state and the silicon ones are on the carbide state, i.e. there is no interaction or diffusion between the $\mathrm{Mg}$ and $\mathrm{SiC}$ layers.

The XRR obtained at $0.154 \mathrm{~nm}(8048 \mathrm{eV})$ with the asprepared sample is shown on figure 3a. The Bragg peaks are narrow, intense and well-defined up to the fifth diffraction order. Some secondary peaks are also observed between the Bragg peaks. We suggest that their existence is due to a small defect or super-structure in the $\mathrm{SiC}$ layers, every two periods. Based on indications from XES, a fit of the experimental XRR curves is made using a two units period. Fitted parameters, i.e. the thickness and density of the $\mathrm{Mg}$ and $\mathrm{SiC}$ layers and interface roughness, deduced using the IMD code [22] are given in table 1 . It can be seen that the rms interfacial roughness is quite large, specially for the $\mathrm{Mg}$ layers and that the density of the $\mathrm{SiC}$ layers is that of the bulk $\mathrm{SiC}$ whereas the $\mathrm{Mg}$ layers have a density slightly smaller than the one of the Mg metal.

In figure 4 the UV reflectivity at $30.4 \mathrm{~nm}(40.7 \mathrm{eV})$ obtained in a $\theta-2 \theta$ scan for an as-prepared sample is shown. The simulated reflectivity for the corresponding ideal structure with thickness parameters of table 1 is reported. The comparison with the experimental curve shows a higher reflectivity of the order of $20 \%$. A much better agreement with the experiment is obtained when the interface roughnesses reported in table 1 , as obtained from XRR measurements at hard x-ray energy, are intro- 
duced into the simulation. It is important to stress that, in agreement with the indication coming from XES (i.e. absence of important interdiffusion or chemical reaction at the interfaces), the optical performance of as-prepared multilayers is substantially limited by interface roughness.

\subsection{Annealed samples}

We present the $\operatorname{Mg} \mathrm{K} \beta$ and $\mathrm{Si} \mathrm{K} \beta$ x-ray analysis of the annealed $\mathrm{Mg} / \mathrm{SiC}$ multilayers in figure 5 . Because it is not possible to acquire both emissions at the same time, the Si emission band is obtained only at $500^{\circ} \mathrm{C}$. It is observed in figure $5 \mathrm{a}$ that the $\mathrm{Mg}$ valence states are those of the metal up to a temperature of $300^{\circ} \mathrm{C}$. At $350^{\circ} \mathrm{C}$ a slight shoulder begins to grow at a photon energy of $1296 \mathrm{eV}$ where the lineshape of $\mathrm{Mg}_{2} \mathrm{Si}$ presents its maximum (see Fig. 1). At $400^{\circ} \mathrm{C}$ this shoulder is well developed and its maximum is slightly shifted toward the low photon energies, consistent with the shift between the maxima of pure $\mathrm{Mg}$ and $\mathrm{Mg}_{2} \mathrm{Si}$ spectra. Then, there is no more evolution up to $500^{\circ} \mathrm{C}$. The silicon emission band, figure $5 \mathrm{~b}$, shows that at this highest temperature the silicon atoms are in a chemical environment like the one of $\mathrm{Mg}_{2} \mathrm{Si}$. This behavior of the magnesium and silicon atoms evidences the formation of the magnesium silicide at the various interfaces of the stack.

This is confirmed by fitting the $\mathrm{Mg} \mathrm{K} \beta$ lineshape by a weighted sum (linear combination) of the reference spectra as shown in the figure 6 . An equal contribution of pure $\mathrm{Mg}$ and $\mathrm{Mg}_{2} \mathrm{Si}$ is necessary to account for the shape of the spectrum of the sample after an annealing at $500^{\circ} \mathrm{C}$. This means that a part of the magnesium atoms has reacted with the silicon atoms from the $\mathrm{SiC}$ layers to form the silicide. This is consistent with the observation that the silicon atoms have reacted to form $\mathrm{Mg}_{2} \mathrm{Si}$ with the magnesium atoms of the Mg layers (Fig. 5b). It could be presumed that the shoulder appearing on the Mg spectrum of the highly annealed multilayers is due to an oxidation of the $\mathrm{Mg}$ atoms because the maximum of the $\mathrm{MgO}$ emission is at the same emission energy as the shoulder of the $\mathrm{Mg}_{2} \mathrm{Si}$ emission (see Fig. 1a). However, we can rule out this possibility because even when introducing some oxide contribution in the fit, it is not possible to account for the energy shift of the maximum and to improve the fit in the range of the shoulder.

The evolution of the reflectivity obtained at $1.33 \mathrm{~nm}$ $(932 \mathrm{eV})$ at the first Bragg order as a function of the annealing temperature is presented in figure 7 . The same behavior is observed for the second Bragg order. First, by annealing at $200^{\circ} \mathrm{C}$, the reflectivity decreases slightly. Between 200 and $250^{\circ} \mathrm{C}$ a strong decrease $(80 \%)$ of the reflectivity occurs. This decrease continues up to a temperature of $350^{\circ} \mathrm{C}$. Another step occurs between 350 and $400^{\circ} \mathrm{C}$ after which the reflectivity diminishes almost entirely. This last step is in agreement with the chemical transformation that occurs within the sample between 350 and $400^{\circ} \mathrm{C}$ as indicated by XES.

We present the evolution of the XRR curves at $0.154 \mathrm{~nm}$ $(8048 \mathrm{eV})$ as a function of the annealing temperature in figure $3 \mathrm{a}-\mathrm{f}$ up to $500^{\circ} \mathrm{C}$. Five Bragg peaks can be observed. There is no significant evolution of the intensity and width 
of the various Bragg peaks up to $200^{\circ} \mathrm{C}$. From $300^{\circ} \mathrm{C}$, the Bragg peaks are less intense and well-defined only up to the third diffraction order. This change is correlated with a decrease of the background intensity as shown in figure 8a.

The simulation of these reflectivity curves shows that the contrast of the refractive index decreases between the $\mathrm{Mg}$ and SiC layers when going from 200 to $300^{\circ} \mathrm{C}$. This can be explained by a development of the roughness or of the interdiffusion between the layers [23]. However, the latter can be ruled out because no chemical diffusion has been evidenced by XES. The absence of diffusion is also confirmed by looking at the value of the critical angle for the total reflection (Fig. 8a). It is almost the same $\left(0.211^{\circ}\right)$ for both annealing temperatures, meaning that the mean optical index and threfore the composition of the sample does not change. Thus, the evolution of the reflectivity at $0.154 \mathrm{~nm}$ between 200 and $300^{\circ} \mathrm{C}$ can be explained by an increase of the interfacial roughness. This is probably due to the crystallization of the Mg layers and should be confirmed by diffraction measurements. When annealed at $400^{\circ} \mathrm{C}$, see figure $8 \mathrm{~b}$, it is observed that the Bragg peaks are less intense and become broader. The structure of the stack has almost disappeared due to the formation of the $\mathrm{Mg}_{2} \mathrm{Si}$ compound as evidenced by XES. This is also confirmed by the shift of the critical angle down to $0.174^{\circ}$ at $400^{\circ} \mathrm{C}$, showing that the mean index and thus the composition of the multilayer has changed.

\section{Conclusion}

We studied the thermal stabilty of periodic $\mathrm{Mg} / \mathrm{SiC}$ multilayers up to $500^{\circ} \mathrm{C}$ by the combination of XRR, UVR and XES techniques to show the possible thermally activated evolution of the system both through morphology and interface processes. We have shown that the as-prepared samples do not present interfacial compounds but have quite large interfacial rms roughness.

Upon annealing, a critical temperature for a strong decrease of the reflectivity has been reported in the literature, but the various authors do not agree on its value, $200^{\circ} \mathrm{C}[5]$ or $300^{\circ} \mathrm{C}$ [6]. In this work, we have found two critical temperatures for which we have observed an important change of the optical and chemical properties. The reflectivity is quite constant up to $200^{\circ} \mathrm{C}$ after which it drops drastically, very probably due to the development of the interfacial roughness. Thus, this kind of multilayer is thermally stable only for application requiring no heating higher than $200^{\circ} \mathrm{C}$.

A second critical temperature has been observed between 350 and $400^{\circ} \mathrm{C}$ that corresponds to the destruction of the multilayer due to the formation of magnesium silicide resulting from the chemical reaction between the magnesium and silicon atoms. This leads to another very strong loss of reflectivity.

This paper shows that the knowledge and control of the microscopic processes governing the interface chemistry and morphology are the key aspects to be improved in order to optimize the optical performances and the overall stability of $\mathrm{Mg} / \mathrm{SiC}$ multilayers. 
Acknowledgments : Pr. R. Gauvin from McGill University is thanked for providing us with the polished $\mathrm{Mg}$ sample.

\section{References}

1. M. Yanagihara, K. Yamashita, Multilayers for Soft and Hard X-rays, in X-ray Spectrometry: Recent Technological Advances (Eds. K. Tsuji, J. Injuk, R. van Grieken, John Wiley \& Sons, 2004)

2. I. Yoshikawa, M. Nakamura, M. Hirahara, Y. Takizawa, K. Yamashita, H. Kunieda, T. Yamazaki, K. Misaki, A. Yamaguchi, J. Geophys. Res. 102, 19897 (1997)

3. B.R. Sandel, A.L. Broadfoot, C.C. Curtis, R.A. King, T.C. Stone, R.H. Hill, J. Chen, O.H.W. Siegmund, R. Raffanti, D.D. Allred, R.S. Turley, D.L. Gallagher, Space Sci. Rev. 91, 197 (2000)

4. D.L. Windt, S. Donguy, J. Seely, B. Kjornrattanawanich, Appl. Opt. 9, 1835 (2004)

5. T. Ejima, Y. Kondo, M. Watanabe, Jpn. J. Appl. Phys. 40, $376(2001)$

6. H. Takenaka, S. Ichimaru, T. Ohchi, E.M. Gullikson, J. Elec. Spec. Rel. Phenom. 144, 1047 (2005)

7. F. Caldarelli, Materials Handbook (Springer-Verlag, London, 2000)

8. S. Veena Kumari, V.K. Vaidyan, K.G. Sathyanarayana, J. Mater. Sci. 27, 5504 (1992)

9. V. Fournier, P. Marcus, I. Olefjord, Surf. Interface Anal. 34, $494(2002)$

10. A.L.K. Tan, A.M. Soutar, I.F. Annergren, Y.N. Liu, Surf. Coat. Technol. 198, 478 (2005)
11. P. Jonnard, I. Jarrige, R. Benbalagh, H. Maury, J.-M. André, Z. Dankhazi, G. Rolland, Surf. Sci. 589, 164 (2005)

12. H. Maury, P. Jonnard, J.-M. André, J. Gautier, M. Roulliay, F. Bridou, F. Delmotte, M.-F. Ravet, A. Jérome, P. Holliger, Thin Solid Films 514, 278 (2006)

13. H. Maury, P. Jonnard, J.-M. André, J. Gautier, F. Bridou, F. Delmotte, M.-F. Ravet, Surf. Sci. 601, 2315 (2007)

14. H. Maury, PhD Thesis, Université Pierre et Marie Curie, Paris, 2007

15. L. Névot, B. Pardo, J. Corno, Rev. Phys. Appl. 23, 1675 (1988)

16. J.-M. André, A. Avila, R. Barchewitz, R. Benbalagh, R. Delaunay, D. Druart, P. Jonnard, H. Ringuenet, Eur. Phys. J. Appl. Phys. 31, 147 (2005)

17. S. Nannarone, F. Borgatti, A. De Luisa, B.P. Doyle, G.C. Gazzadi, A. Giglia, P. Finetti, N. Mahne, L. Pasquali, M. Pedio, G. Selvaggi, G. Naletto, M.G. Pelizzo, G. Tondello, AIP Conf. Proc. 708, 450 (2004)

18. C. Bonnelle, F. Vergand, P. Jonnard, J.-M. André, P.-F. Staub, P. Avila, P. Chargelègue, M.-F. Fontaine, D. Laporte, P. Paquier, A. Ringuenet, and B. Rodriguez, Rev. Sci. Instrum. 65, 3466 (1994)

19. P. Jonnard, F. Vergand, C. Bonnelle, E. Orgaz, M. Gupta, Phys. Rev. B57, 12111 (1998)

20. I. Jarrige, P. Jonnard, N. Frantz-Rodriguez, K. Danaie, A. Bossebœuf, Surf. Interface Anal. 34, 694 (2002)

21. E. Belin-Ferré, A. Gheorghiu de la Rocque, M.-F. Fontaine, J. Thirion, J. Willekens, M. Brinza, G.J. Adrianssens, J. Non-Cryst. Sol. 338-340, 240 (2004)

22. D. L. Windt, Comp. Phys. 12, 360 (1998)

23. V. Dupuis, M.-F. Ravet, C. Tête, M. Piecuch, Y. Lepêtre, R. Rivoira, E. Ziegler, J. Appl. Phys. 68, 5146 (1990) 
Table 1. Parameters of the as-prepared $\mathrm{Mg} / \mathrm{SiC}$ multilayer deduced from XRR at $0.154 \mathrm{~nm}$. The relative density is the density of the layer divided by the density of the bulk corresponding material.

\begin{tabular}{lccc}
\hline layer & thickness $(\mathrm{nm})$ & relative density & roughness $(\mathrm{nm})$ \\
\hline $\mathrm{Mg}$ & 12.1 & 0.94 & 1.7 \\
\hline $\mathrm{SiC}$ & 4.7 & 1.00 & 0.9 \\
\hline
\end{tabular}



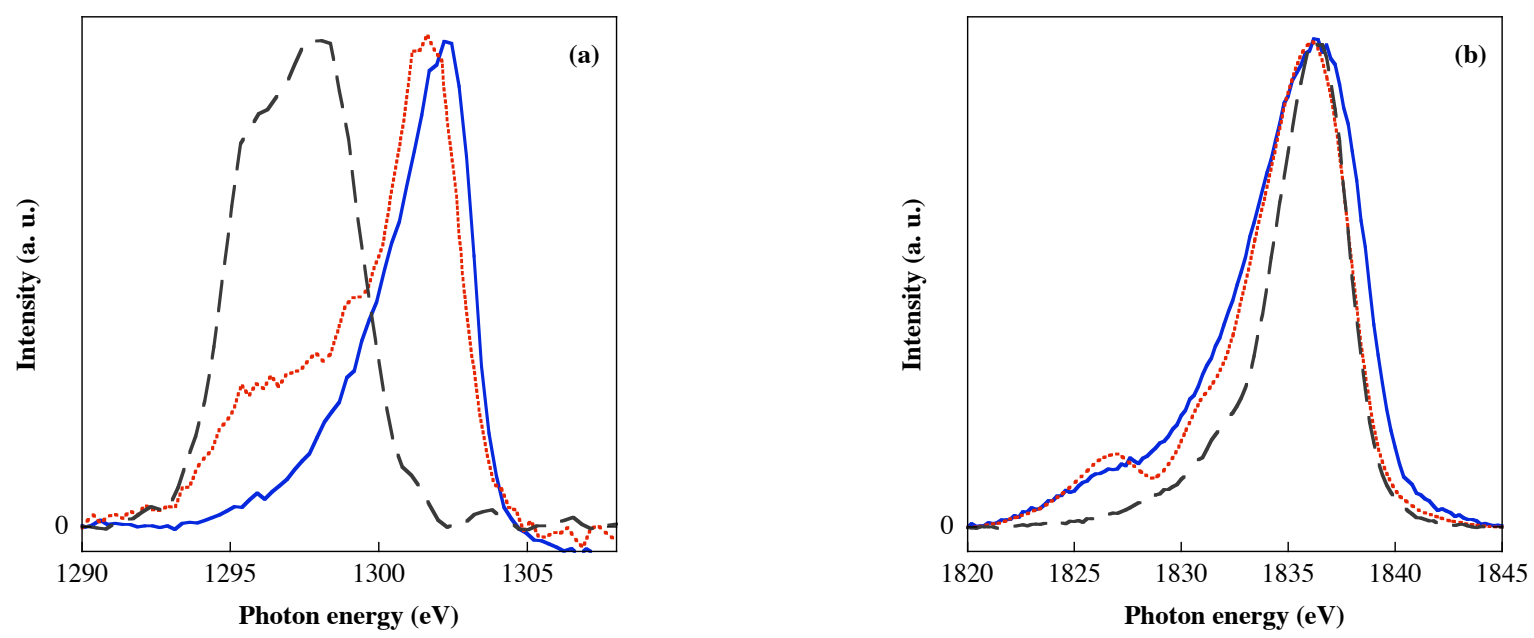

Fig. 1. (a) $\mathrm{Mg} \mathrm{K} \beta$ x-ray emission bands from reference compounds: metal $\mathrm{Mg}$ (solid line), $\mathrm{Mg}_{2} \mathrm{Si}$ (dotted line) and $\mathrm{MgO}$ (dashed line); (b) Si K $\beta$ x-ray emission bands from reference compounds: $\mathrm{Mg}_{2} \mathrm{Si}$ (dashed line), cystalline SiC (solid line) and amorphous $\mathrm{SiC}$ (dotted line). 

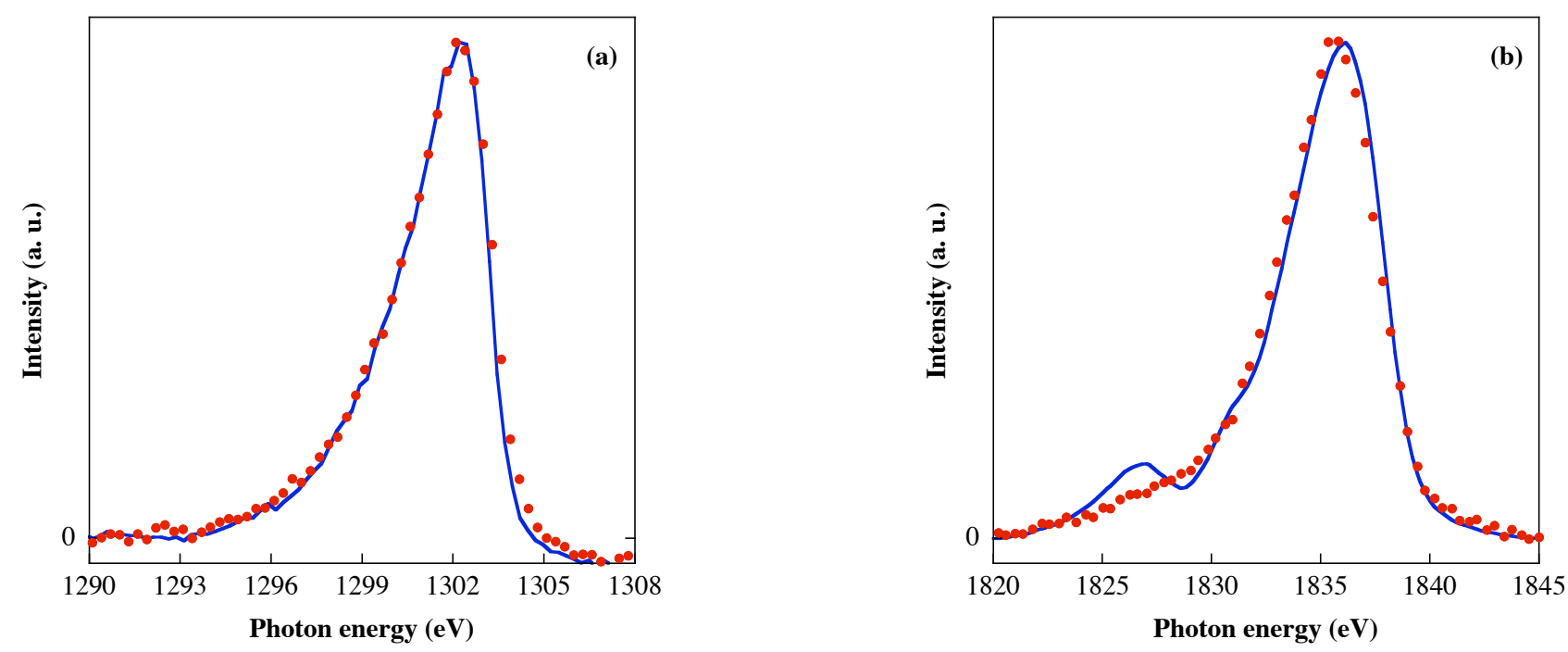

Fig. 2. (a) $\mathrm{Mg} \mathrm{K} \beta$ x-ray emission bands from an as-prepared $\mathrm{Mg} / \mathrm{SiC}$ multilayer (dots) and metal $\mathrm{Mg}$ (solid line); (b) Si $\mathrm{K} \beta$ x-ray emission bands from from an as-prepared $\mathrm{Mg} / \mathrm{SiC}$ multilayer (dots) and crystalline SiC (solid line). 


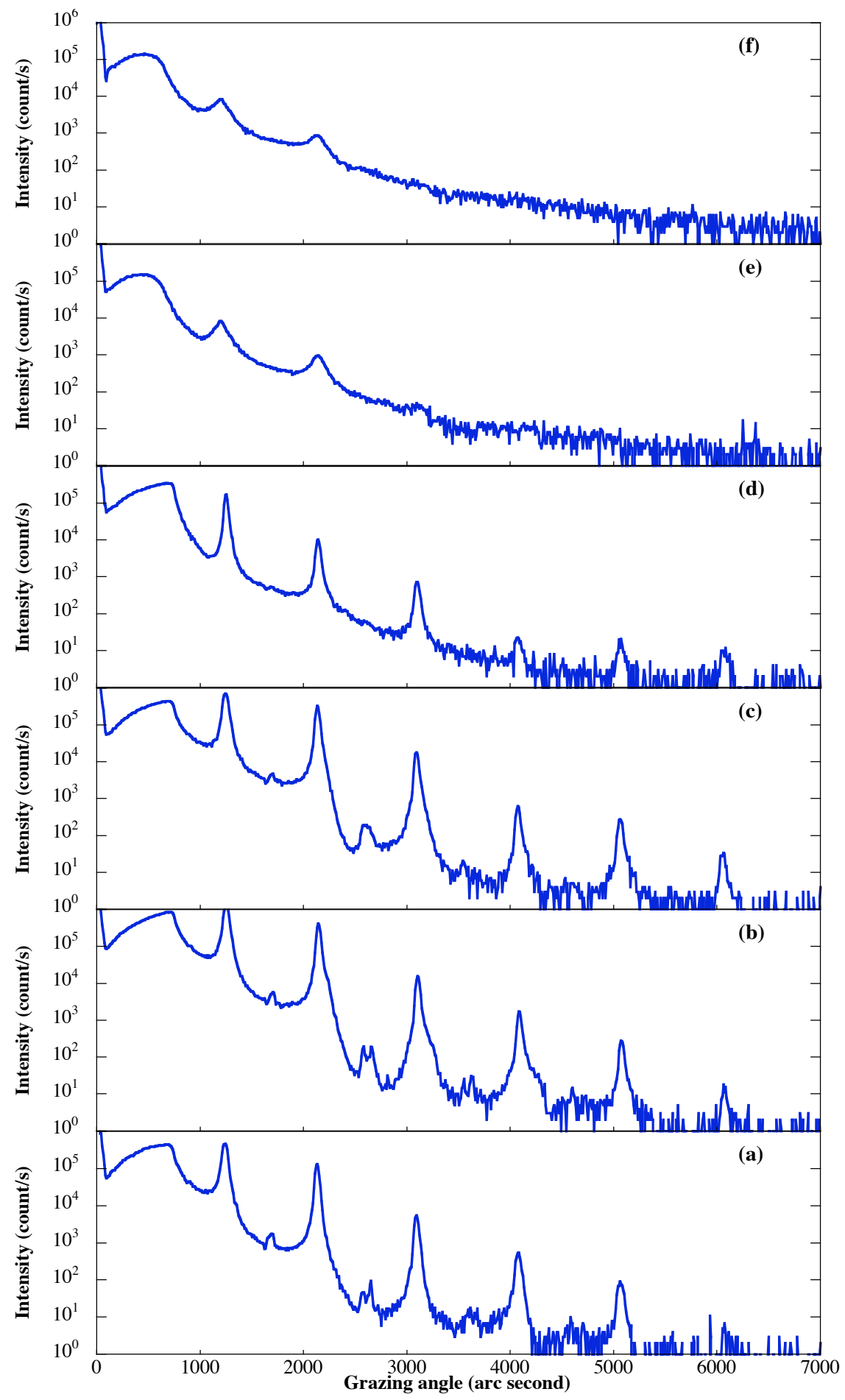

Fig. 3. Reflectivity curves at $0.154 \mathrm{~nm}(8048 \mathrm{eV})$ of the $\mathrm{Mg} / \mathrm{SiC}$ multilayers: as-prepared (a), annealed at $100^{\circ} \mathrm{C}(\mathrm{b}), 200^{\circ} \mathrm{C}$ (c), $300^{\circ} \mathrm{C}(\mathrm{d}), 400^{\circ} \mathrm{C}(\mathrm{e})$ and $500^{\circ} \mathrm{C}(\mathrm{f})$. 


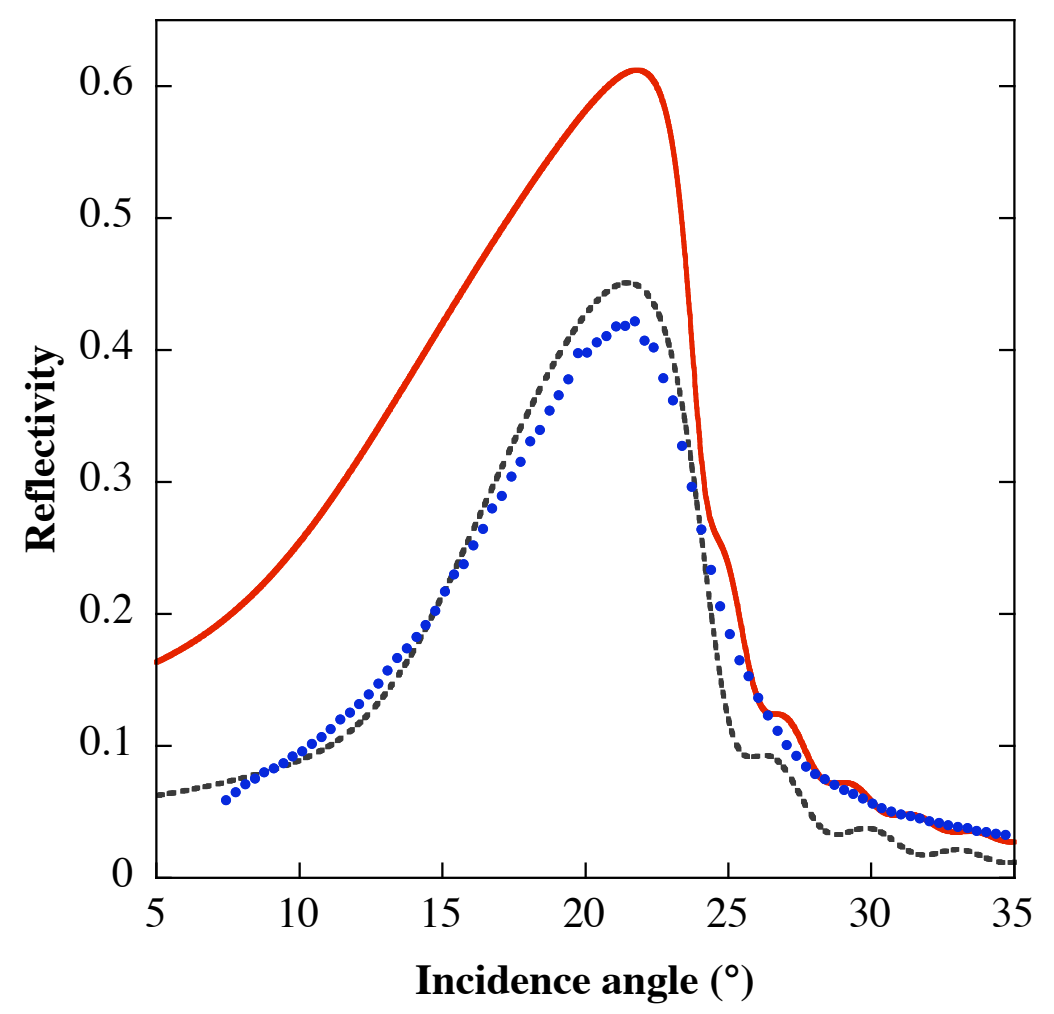

Fig. 4. Reflectivity curve at $30.4 \mathrm{~nm}(40.7 \mathrm{eV})$ of the as-prepared $\mathrm{Mg} / \mathrm{SiC}$ multilayer (dots) compared to simulated curves for a perfect structure (solid line) and for a structure with the parameters listed in the table 1 (dotted line). 

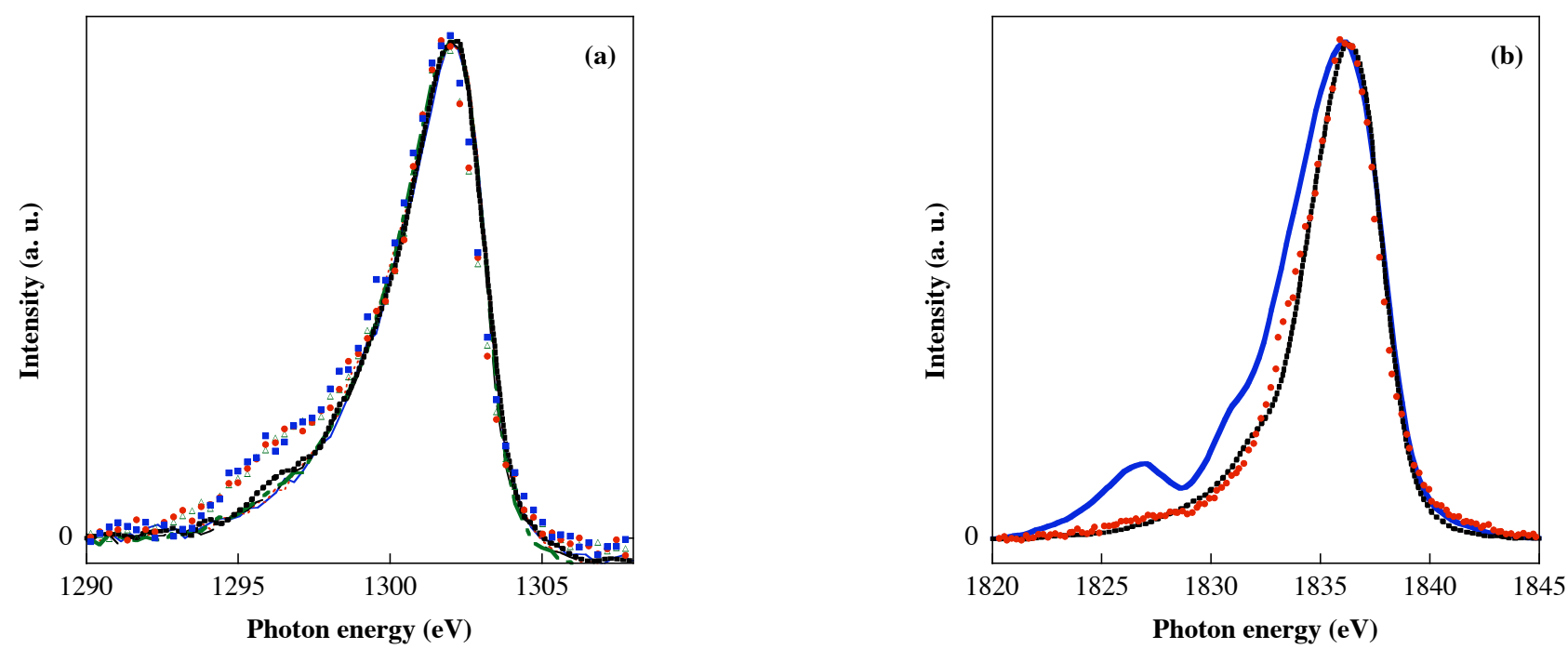

Fig. 5. (a) $\mathrm{Mg} \mathrm{K} \beta$ x-ray emission bands from $\mathrm{Mg} / \mathrm{SiC}$ multilayers: as-prepared, 200,250 and $300^{\circ} \mathrm{C}$ (thin solid lines); $350^{\circ} \mathrm{C}$ (thick dotted line); 400, 450 and $500^{\circ} \mathrm{C}$ (dots). (b) Si $\mathrm{K} \beta$ x-ray emission bands from from the $\mathrm{Mg} / \mathrm{SiC}$ multilayer annealed at $500^{\circ} \mathrm{C}$ (dots) compared to the spectra of $\mathrm{Mg}_{2} \mathrm{Si}$ (solid line) and cystalline $\mathrm{SiC}$ (dotted line). 


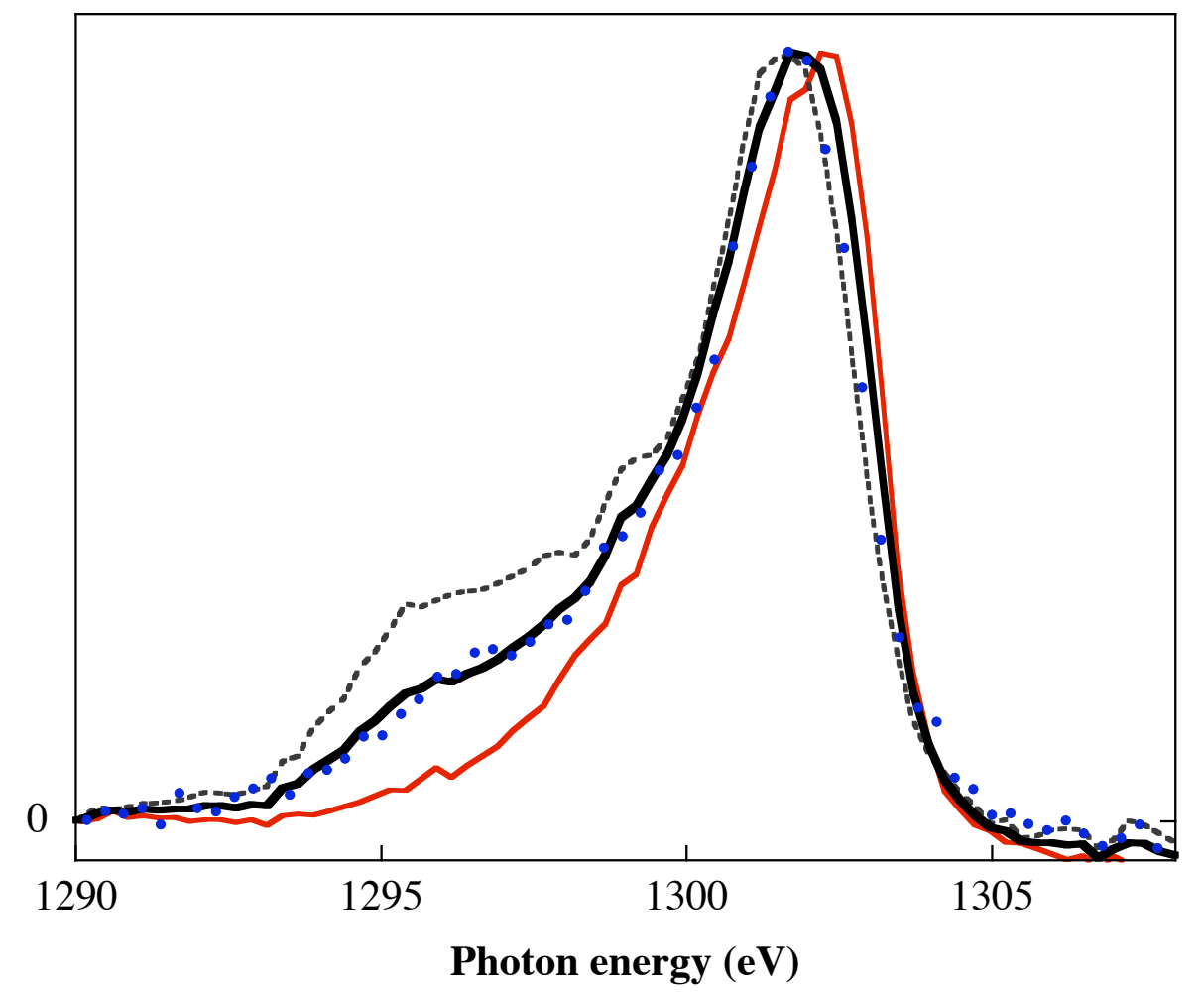

Fig. 6. $\mathrm{Mg} \mathrm{K} \beta$ x-ray emission band from the $\mathrm{Mg} / \mathrm{SiC}$ multilayer annealed at $500^{\circ} \mathrm{C}$ (dots) compared to the ones of pure $\mathrm{Mg}$ (thin solid line) and $\mathrm{Mg}_{2} \mathrm{Si}$ (thin dotted line) and to a weighted sum of corresponding to $50 \% \mathrm{Mg}+50 \% \mathrm{Mg}_{2} \mathrm{Si}$ (thick solid line). 


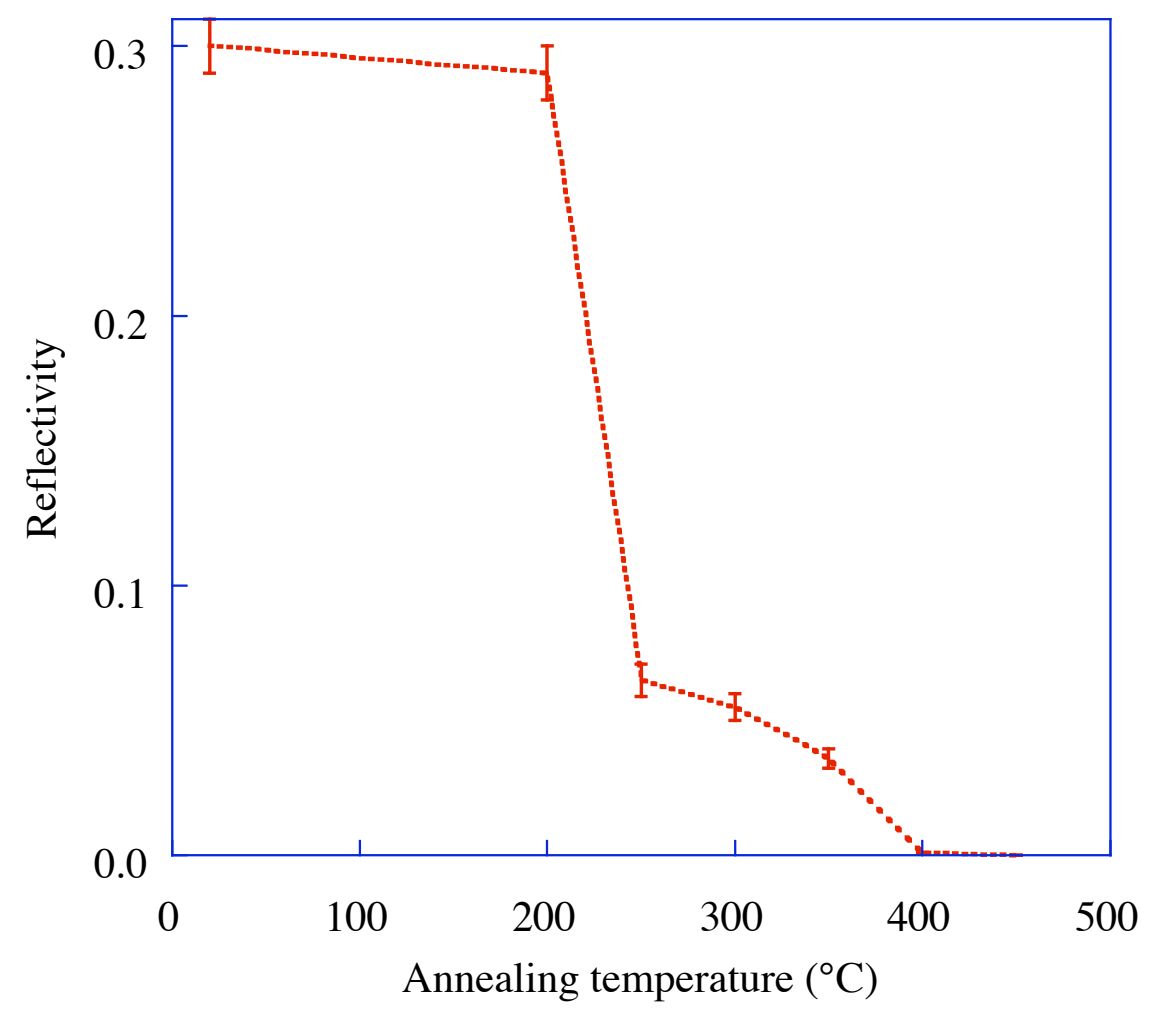

Fig. 7. Evolution of the reflectivity at $1.33 \mathrm{~nm}(932 \mathrm{eV})$ of the $\mathrm{Mg} / \mathrm{SiC}$ multilayer as a function of the annealing temperature. 

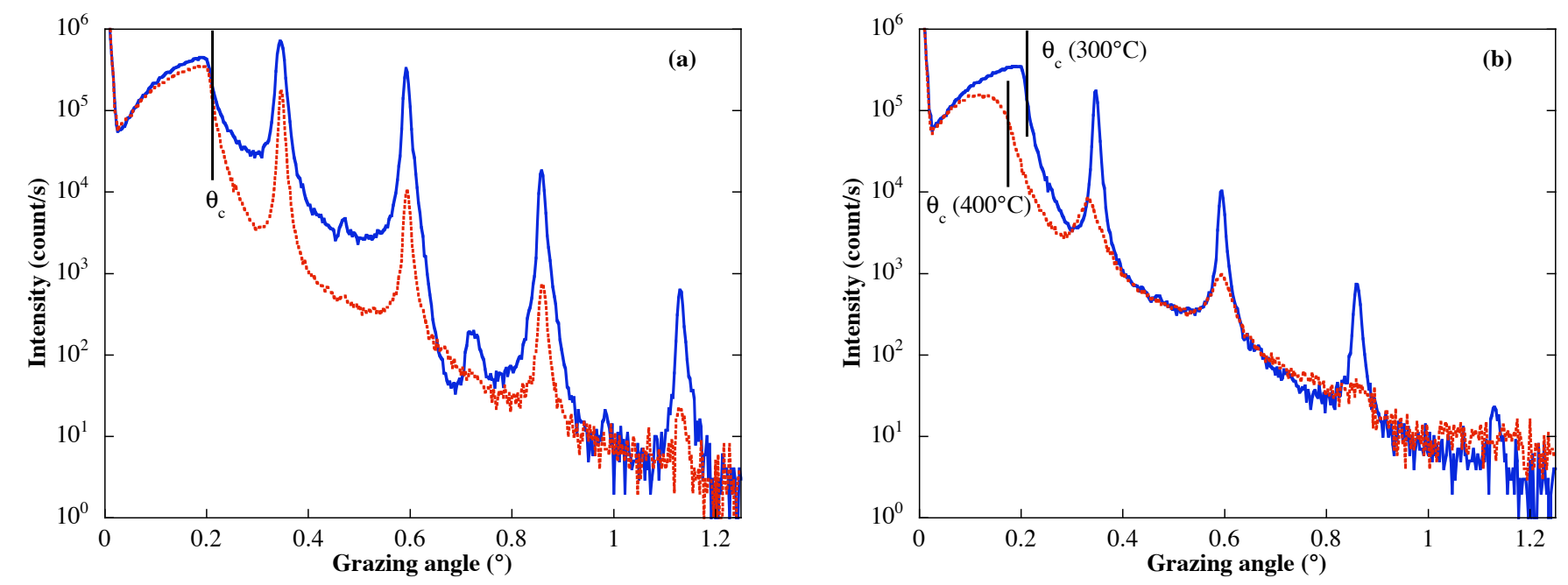

Fig. 8. Reflectivity curves at $0.154 \mathrm{~nm}(8048 \mathrm{eV})$ of the $\mathrm{Mg} / \mathrm{SiC}$ multilayer: (a) annealed at 200 (solid line) and $300^{\circ} \mathrm{C}($ dotted line); (b) annealed at 300 (solid line) and $400^{\circ} \mathrm{C}$ (dotted line). The vertical bars indicate the critical angles for total reflection. 